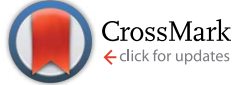

Cite this: J. Mater. Chem. A, 2016, 4, 17678

Received 17th August 2016 Accepted 21st October 2016

DOI: 10.1039/c6ta07067a

www.rsc.org/MaterialsA

\section{Direct application of cobaltite-based perovskite cathodes on the yttria-stabilized zirconia electrolyte for intermediate temperature solid oxide fuel cells $\uparrow$}

\author{
Kongfa Chen, $\star^{\text {ab }} \mathrm{Na} \mathrm{Li,t^{ \textrm {bc } }} \mathrm{Na} \mathrm{Ai},{ }^{\mathrm{b}}$ Meng Li, ${ }^{\mathrm{d}} \mathrm{Yi}_{\mathrm{i}}$ Cheng, ${ }^{\mathrm{b}}$ William D. A. Rickard, ${ }^{\mathrm{e}}$ Jian Li ${ }^{\mathrm{d}}$ \\ and San Ping Jiang*b
}

\begin{abstract}
In this communication, cobaltite-based perovskite (CBP) cathodes are directly applied on the yttria-stabilized zirconia (YSZ) electrolyte via an in situ assembly process without the addition of a doped ceria interlayer and pre-sintering at high temperatures. The results demonstrate for the first time that a CBP electrode/YSZ electrolyte interface can be formed in situ under cathodic polarization at a solid oxide fuel cell (SOFC) operating temperature of $750{ }^{\circ} \mathrm{C}$. Nevertheless, the performance of cells with Sr-containing CBP cathodes deteriorates due to the surface segregation of $\mathrm{Sr}$ species and formation of a Sr-rich reaction layer at the interface. However, the stability and power density of cells with in situ assembled CBP cathodes can be further enhanced by B-site doping or by using a Sr-free CBP. The direct application of CBPs on the YSZ electrolyte revolutionizes the design of intermediate temperature SOFCs.
\end{abstract}

\section{Introduction}

Solid oxide fuel cells (SOFCs) are an energy conversion device that directly convert the chemical energy of fuels such as hydrogen, natural gas and hydrocarbons to electrical energy with a very high efficiency and much less greenhouse gas emission as compared to conventional internal combustion engines. ${ }^{1}$ It is vital to reduce the operating temperature of SOFCs from $\sim 1000{ }^{\circ} \mathrm{C}$ to the intermediate temperature range of $600-800{ }^{\circ} \mathrm{C}$, IT-SOFCs, in order to significantly widen the

${ }^{a}$ College of Materials Science and Engineering, Fuzhou University, Fuzhou, Fujian 350108, China

${ }^{b}$ Fuels and Energy Technology Institute \& Department of Chemical Engineering, Curtin University, Perth, WA 6102, Australia. E-mail: s.jiang@curtin.edu.au; Fax: +61 89266 1138; Tel: +61892669804

${ }^{c}$ College of Science, Heilongjiang University of Science and Technology, Harbin 150022, China

${ }^{2}$ State Key Laboratory for Coal Combustion, School of Materials Science and Engineering, Huazhong University of Science and Technology, Wuhan 430074, China eJohn De Laeter Centre \& Department of Physics and Astronomy, Curtin University, Perth, WA 6102, Australia

$\dagger$ Electronic supplementary information (ESI) available. See DOI: 10.1039/c6ta07067a

\$ These authors contributed equally. selection of materials, enable the use of low-cost metallic interconnectors and increase the operation durability of SOFC systems. ${ }^{2}$ Two major strategies have been adopted to enhance the cell power density at reduced temperatures. One strategy is to minimize the ohmic loss by reducing the thickness of the electrolyte layer to $10 \mu \mathrm{m}$ or below by developing anode-supported electrolyte cells. ${ }^{3}$ The other is to reduce the electrode polarization loss by developing a high performance cathode. A manganite based perovskite cathode such as $\mathrm{La}_{0.8} \mathrm{Sr}_{0.2} \mathrm{MnO}_{3+\delta}$ (LSM) shows high activity for the $\mathrm{O}_{2}$ reduction reaction at high temperatures but performs poorly at reduced temperatures due to its negligible ionic conductivity. ${ }^{4}$ The most active cathodes for IT-SOFCs belong to mixed ionic and electronic conducting (MIEC) cobaltite-based perovskites (CBPs) such as $\mathrm{Ba}_{0.5} \mathrm{Sr}_{0.5} \mathrm{Co}_{0.8} \mathrm{Fe}_{0.2} \mathrm{O}_{3-\delta}$ (BSCF), $\mathrm{La}_{0.6} \mathrm{Sr}_{0.4} \mathrm{Co}_{0.2} \mathrm{Fe}_{0.8} \mathrm{O}_{3-\delta}$ (LSCF) and $\mathrm{PrBa}_{0.5} \mathrm{Sr}_{0.5} \mathrm{Co}_{1.5} \mathrm{Fe}_{0.5} \mathrm{O}_{5+\delta}$ (PBSCF), which show excellent electrocatalytic activity for the $\mathrm{O}_{2}$ reduction reaction..$^{5-9}$ Thus CBPs are the preferred choice for cathode materials in IT-SOFCs.

Yttria-stabilized zirconia (YSZ) is the most common electrolyte for IT-SOFCs due to its high mechanical strength and negligible electrical conductivity with the ionic transfer number close to unity. Unfortunately CBPs cannot be directly applied on the YSZ electrolyte due to their high chemical activity with YSZ during the high temperature sintering in the traditional cathode fabrication process. It is well known from experimental as well as theoretical analysis that CBPs react with the YSZ electrolyte, forming insulated reaction phases such as $\mathrm{La}_{2} \mathrm{Zr}_{2} \mathrm{O}_{7}$ and/or $\mathrm{SrZrO}_{3}$ and drastically degrading the performance of a SOFC. ${ }^{10,11}$ Thus in order to use CBP cathodes and to avoid the interfacial reaction, a doped ceria, e.g., Gd-doped ceria (GDC), barrier layer has to be employed between the cathode and YSZ electrolyte. ${ }^{12,13}$ However, the use of a ceria interlayer in a cell requires additional fabrication steps. Typically, the conventional fabrication process of an anode-supported cell with the CBP cathode consists of two separate screen-printing and two separate sintering steps at temperatures of $\sim 1000-1250^{\circ} \mathrm{C}$. This substantially increases the complexity and cost of the cell and 
more importantly increases the risk of the cell degradation and delamination due to the incompatibility in chemical and thermal properties between YSZ and the ceria interlayer. ${ }^{\mathbf{1 4 1 5}}$ The presence of a porous ceria layer also leads to an increase of ohmic resistance due to the poor contact at the ceria/YSZ interface $^{16}$ and loss of the electrocatalytic activity of CBP cathodes due to the migration of Sr to the ceria/YSZ interface to form insulating $\mathrm{SrZrO}_{3} \cdot{ }^{17,18}$ The fabrication complexity and related high fabrication cost have restrained the commercial development of IT-SOFC technology.

We showed recently that electrode/electrolyte interfaces such as LSM on YSZ and LSCF on GDC can be formed under the influence of cathodic polarization without the high temperature sintering step. ${ }^{19}$ The polarization induced interface is characterized by the formation of contact marks and shows comparable electrochemical performance to high temperature sintered LSM and LSCF cathodes. Herein, we demonstrate for the first time that CBP cathodes can be directly applied on the YSZ electrolyte via an in situ assembly process with no requirement of a GDC interlayer and high temperature sintering steps. The in situ assembly process significantly reduces the fabrication steps for SOFCs and the elimination of high temperature sintering avoids the chemical reaction between CBPs and the YSZ electrolyte. The stability and power density of such an in situ assembled CBP can be further significantly enhanced by B-site doping or by using a Sr-free CBP. For example, a cell with a $\mathrm{Sm}_{0.95} \mathrm{Co}_{0.95} \mathrm{Pd}_{0.05} \mathrm{O}_{3-\delta}$ GDC composite cathode shows a high power output of $1.4 \mathrm{~W} \mathrm{~cm}^{-2}$ at $750{ }^{\circ} \mathrm{C}$ and is very stable at $500 \mathrm{~mA} \mathrm{~cm}^{-2}$ over $240 \mathrm{~h}$. The direct application of CBPs on the YSZ electrolyte opens new opportunities for the direct use of a vast range of CBP cathodes for the development of high performance and low cost IT-SOFCs and will have a fundamental impact on the design of SOFCs in general.

\section{Experimental}

Ni-YSZ anode-supported YSZ film planar SOFCs were fabricated by slurry spin coating. ${ }^{20} \mathrm{NiO}$ (J.T. Baker), YSZ (TZ-8Y, Tosoh) and tapioca at a weight ratio of $5: 5: 2.5$ were mixed in a BMT-30D ball mill (Hsiangtai Machinery Industry Co Ltd) for $24 \mathrm{~h}$. The mixed powder was compacted in a stainless steel die (ID $18 \mathrm{~mm}$ ) and pre-sintered at $1000{ }^{\circ} \mathrm{C}$ for $2 \mathrm{~h}$ to form the anode substrates. The anode functional layer (AFL) with $\mathrm{NiO}$ and YSZ at a weight ratio of $5: 5$ and the YSZ thin film were spread on the anode substrates using a spin coater (VTC-100, MTI) and sintered at $1450{ }^{\circ} \mathrm{C}$ for $5 \mathrm{~h}$. The thickness of the AFL layer was $14 \mu \mathrm{m}$. The sintered YSZ film was dense and pinhole free (Fig. S1, ESI $\dagger$ ).

$\mathrm{La}_{0.6} \mathrm{Sr}_{0.4} \mathrm{Co}_{0.2} \mathrm{Fe}_{0.8} \mathrm{O}_{3-\delta}$ (LSCF), $\left(\mathrm{La}_{0.6} \mathrm{Sr}_{0.4}\right)_{0.95} \mathrm{Co}_{0.2} \mathrm{Fe}_{0.7} \mathrm{Nb}_{0.1} \mathrm{O}_{3-\delta}$ (LSCFN), $\left(\mathrm{La}_{0.6} \mathrm{Sr}_{0.4}\right)_{0.95}\left(\mathrm{Co}_{0.2} \mathrm{Fe}_{0.7} \mathrm{Nb}_{0.1}\right)_{0.95} \mathrm{Pd}_{0.05} \mathrm{O}_{3-\delta} \quad$ (LSCFNPd), $\mathrm{La}_{0.95}\left(\mathrm{Co}_{0.2} \mathrm{Fe}_{0.8}\right)_{0.95} \mathrm{Pd}_{0.05} \mathrm{O}_{3-\delta} \quad$ (LCFPd), $\quad \mathrm{Sm}_{0.95} \mathrm{Co}_{0.95} \mathrm{Pd}_{0.05} \mathrm{O}_{3-\delta}$ (SmCPd), $\quad \mathrm{PrBa}_{0.5} \mathrm{Sr}_{0.5} \mathrm{Co}_{1.5} \mathrm{Fe}_{0.5} \mathrm{O}_{5+\delta} \quad$ (PBSCF), $\quad\left(\mathrm{La}_{0.8} \mathrm{Sr}_{0.2}\right)_{0.95^{-}}$ $\mathrm{Mn}_{0.95} \mathrm{Pt}_{0.05} \mathrm{O}_{3-\delta}$ (LSMPt) and $\mathrm{Y}_{0.5} \mathrm{Bi}_{1.5} \mathrm{O}_{3}$ (YSB) powders were prepared by the combined citrate and ethylenediaminetetraacetic acid (EDTA) complexing method. The starting chemicals were $\mathrm{La}\left(\mathrm{NO}_{3}\right)_{3} \cdot 6 \mathrm{H}_{2} \mathrm{O}, \mathrm{Co}\left(\mathrm{NO}_{3}\right)_{2} \cdot 6 \mathrm{H}_{2} \mathrm{O}, \mathrm{Mn}\left(\mathrm{NO}_{3}\right)_{2}$ and $\mathrm{Pd}\left(\mathrm{NO}_{3}\right)_{2}$ from Alfa Aesar, $\mathrm{Sm}\left(\mathrm{NO}_{3}\right)_{3} \cdot 6 \mathrm{H}_{2} \mathrm{O}, \mathrm{Sr}\left(\mathrm{NO}_{3}\right)_{2}, \mathrm{Bi}\left(\mathrm{NO}_{3}\right)_{3} \cdot 5 \mathrm{H}_{2} \mathrm{O}$, $\operatorname{Pr}\left(\mathrm{NO}_{3}\right)_{3} \cdot 6 \mathrm{H}_{2} \mathrm{O}, \mathrm{H}_{2} \mathrm{Cl}_{6} \mathrm{Pt} \cdot x \mathrm{H}_{2} \mathrm{O}$ and $\mathrm{C}_{4} \mathrm{H}_{4} \mathrm{NNbO}_{9} \cdot x \mathrm{H}_{2} \mathrm{O}$ from
Sigma-Aldrich, $\mathrm{Ba}\left(\mathrm{NO}_{3}\right)_{2}$ (Scharlau), $\mathrm{Fe}\left(\mathrm{NO}_{3}\right)_{3} \cdot 9 \mathrm{H}_{2} \mathrm{O}$ (Chem Supply), $\mathrm{Y}\left(\mathrm{NO}_{3}\right)_{3} \cdot 6 \mathrm{H}_{2} \mathrm{O}$ (Acros Organics), citric acid (Chem Supply), EDTA (Acros Organics) and ammonia solution (Ajax Finechem). The molar ratio of metal ions/citric acid/EDTA was $1: 1.5: 1$. Most of the resultant cathode powders were calcined at $900{ }^{\circ} \mathrm{C}$ in air for $2 \mathrm{~h}$, except that PBSCF powder was calcined at $1050{ }^{\circ} \mathrm{C}$ for $10 \mathrm{~h}$ and YSB powder was calcined at $750{ }^{\circ} \mathrm{C}$ in air for $2 \mathrm{~h}$. The formation of desired perovskite phases was confirmed by X-ray diffraction using a Bruker D8 Advance (Fig. S2, ESI $\dagger$ ).

The as-prepared cathode powder was dispersed in an ink vehicle (Fuel Cell Materials) at a weight ratio of $5: 5$. In some cases, $40 \mathrm{wt} \% \mathrm{Gd}_{0.1} \mathrm{Ce}_{0.9} \mathrm{O}_{1.95}$ powder (GDC, AGC Seimi Chemical Co Ltd) or YSB powder was added to form composite electrodes. The ink was prepared on the YSZ electrolytes by slurry coating and dried at $100{ }^{\circ} \mathrm{C}$ for $2 \mathrm{~h}$ to form the in situ assembled electrodes without further pre-sintering. The effective cathode area was $0.25 \mathrm{~cm}^{2}$. Pt ink (Gwent Electronic Materials Ltd) was painted on the electrodes as a current collector and dried at $150{ }^{\circ} \mathrm{C}$ for $2 \mathrm{~h}$ without pre-heat-treatment.

The single cell was sealed on an alumina tube with a ceramic sealant (Ceramabond 552, AREMCO Products Inc.) and was heated to $750{ }^{\circ} \mathrm{C}$ at a heating rate of $5{ }^{\circ} \mathrm{C} \mathrm{min}{ }^{-1}$. Hydrogen at a flow rate of $50 \mathrm{ml} \mathrm{min}{ }^{-1}$ was fed to the anode, and the cathode was exposed to stationary air. The NiO-YSZ anode was reduced in hydrogen for $1 \mathrm{~h}$ before the electrochemical testing. The electric conductivity of the Pt current collector was examined and the results indicate that the organic additives in the Pt ink were completely decomposed after the heat-treatment at the operating temperature of $750{ }^{\circ} \mathrm{C}$ for $1 \mathrm{~h}$. The cell performance was evaluated by using a Gamry ref. 3000 Potentiostat. Electrochemical impedance curves were measured in a frequency range of $100 \mathrm{kHz}$ to $0.1 \mathrm{~Hz}$ with a signal amplitude of $10 \mathrm{mV}$ under open circuit. Cell ohmic resistance, $R_{\Omega}$, was obtained from the high frequency intercept, and is the sum of the ohmic resistance of the electrolyte, electrode and contact resistance at the electrode/electrolyte. The overall electrode polarization resistance of the cell $R_{\mathrm{E}}$ was estimated by using the differences between the high and low frequency intercepts. To evaluate the cell stability, cell voltage was recorded at a constant current of $500 \mathrm{~mA} \mathrm{~cm}^{-2}$ at $750{ }^{\circ} \mathrm{C}$, or $250 \mathrm{~mA} \mathrm{~cm}^{-2}$ at $600{ }^{\circ} \mathrm{C}$.

The microstructure of the cathodes was examined using scanning electron microscopy (SEM, Zeiss NEON 40EsB). The in situ assembled cathodes were removed by using adhesive tape, and the elemental distribution on the YSZ electrolyte surface was analyzed by time of flight secondary ion mass spectroscopy (ToF-SIMS) using a Tescan Lyra focused ion beam-SEM (FIBSEM). A cross-sectional lamella at the electrode/electrolyte surface was prepared in the FIB-SEM. Microstructure and elemental mapping analyses of the lamella were carried out using high angle annular dark field scanning transmission electron microscopy (HAADF-STEM, FEI Titan G2 80-200 TEM/STEM with ChemiSTEM Technology) at $200 \mathrm{kV}$. In some cases, the cathodes were removed from the YSZ surface by ultrasonic treatment in $32 \% \mathrm{HCl}$ solution. The YSZ surface was then examined by tapping mode atomic force microscopy (AFM) using a Dimension FastScan AFM (Bruker). 


\section{Results and discussion}

\subsection{In situ assembly processes and interface formation}

Fig. 1A shows the novel in situ assembly process as compared to the conventional fabrication processes. In the in situ assembly process, the as-prepared CBP cathode ink was prepared on anode-supported YSZ electrolyte films by slurry coating and drying at $100{ }^{\circ} \mathrm{C}$ for $2 \mathrm{~h}$ to form the in situ assembled CBP electrode without a ceria-based interlayer and additional sintering steps. The in situ assembly process involves only one screen-printing step and eliminates the additional fabrication and sintering steps associated with the ceria interlayer. This substantially decreases the fabrication steps and potentially reduces the cost of the cell fabrication.
The chemical reactivity between CBPs and the YSZ electrolyte was studied on a LSCF cathode. XRD analysis of the LSCF-YSZ couple powder shows that LSCF reacts with YSZ at $800{ }^{\circ} \mathrm{C}$, forming a secondary phase of $\mathrm{SrZrO}_{3}$, but is chemically stable at $750{ }^{\circ} \mathrm{C}$ (Fig. 1B). Thus the testing temperature for the in situ assembled CBP cathodes was controlled at $750{ }^{\circ} \mathrm{C}$ or below in this study. Fig. 1C shows the typical microstructure of an in situ assembled LSCF cathode on a Ni-YSZ anode supported YSZ electrolyte cell. The in situ assembled LSCF electrode is $18 \mu \mathrm{m}$ thick and porous, forming intimate physical contacts with the YSZ electrolyte. The YSZ electrolyte thickness was maintained at $\sim 8 \mu \mathrm{m}$ in this study.

Fig. 1D shows typical AFM images of the YSZ electrolyte surface with selected in situ assembled $\left(\mathrm{La}_{0.6} \mathrm{Sr}_{0.4}\right)_{0.95} \mathrm{Co}_{0.2} \mathrm{Fe}_{0.7} \mathrm{Nb}_{0.1} \mathrm{O}_{3-\delta}$
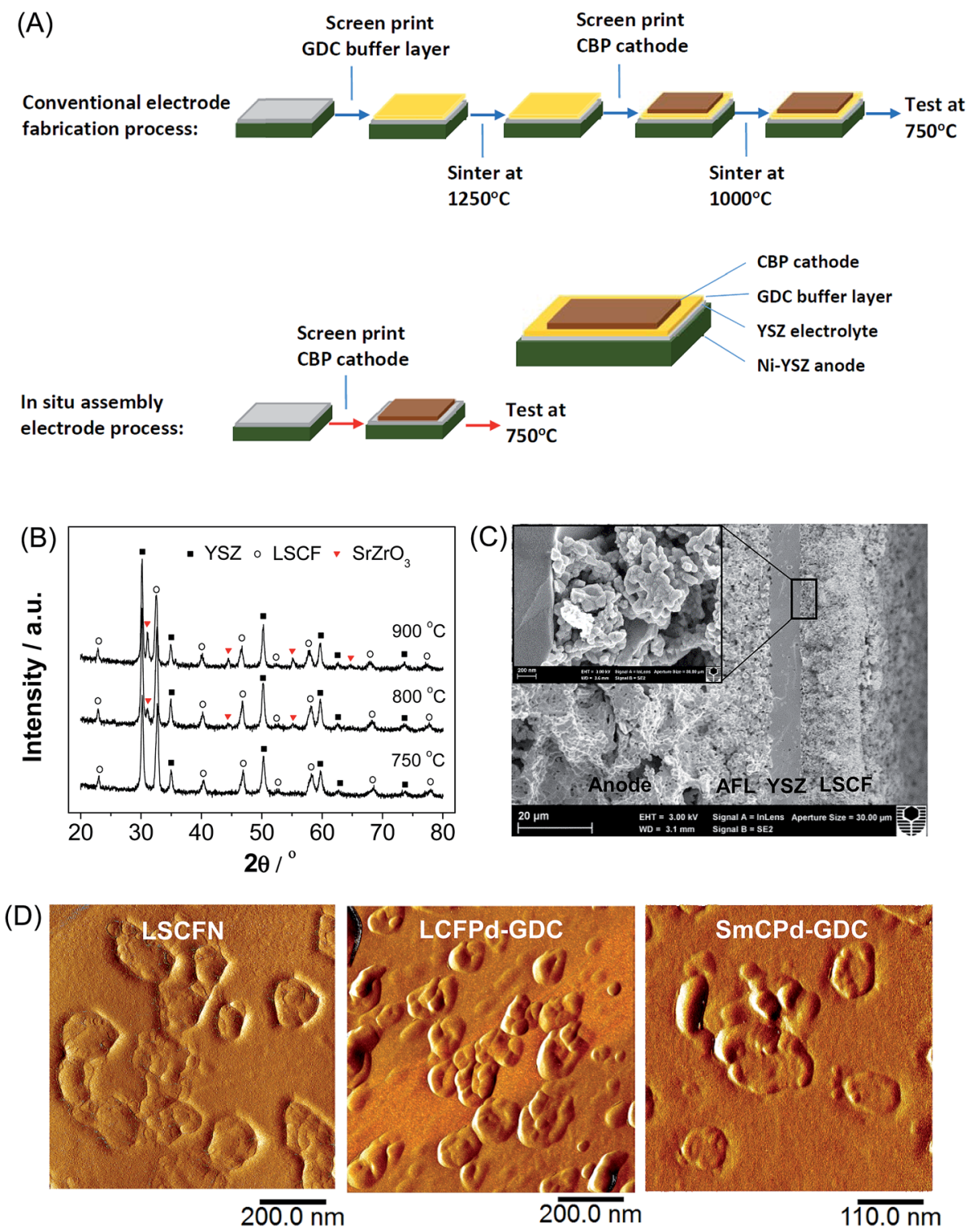

Fig. 1 (A) Fabrication steps for cells with a conventionally high temperature sintered LSCF and GDC interlayer process and with in situ assembled LSCF; (B) XRD patterns of LSCF-YSZ (5:5, w/w) couple oxides after heat-treatment at $750-900{ }^{\circ} \mathrm{C}$ for $4 \mathrm{~h}$; and (C) SEM image of the cross section of an anode-supported YSZ electrolyte cell with an in situ assembled LSCF electrode and the inset shows the YSZ/LSCF interface. (D) Typical AFM images of the acid etched YSZ surface in contact with in situ assembled LSCFN, LCFPd-GDC and SmCPd-GDC cathodes after the cell stability test at $500 \mathrm{~mA} \mathrm{~cm}{ }^{-2}$ and $750{ }^{\circ} \mathrm{C}$ for $180-240 \mathrm{~h}$. 
(LSCFN), $\quad \mathrm{La}_{0.95}\left(\mathrm{Co}_{0.2} \mathrm{Fe}_{0.8}\right)_{0.95} \mathrm{Pd}_{0.05} \mathrm{O}_{3-\delta} \quad$ (LCFPd)-GDC and $\mathrm{Sm}_{0.95} \mathrm{Co}_{0.95} \mathrm{Pd}_{0.05} \mathrm{O}_{3-\delta}(\mathrm{SmCPd})-\mathrm{GDC}$ cathodes after cell stability tests at $500 \mathrm{~mA} \mathrm{~cm}{ }^{-2}$ and $750{ }^{\circ} \mathrm{C}$ for $180-240 \mathrm{~h}$. The cathodes were removed by acid treatment. Contact marks in the size range of 60-260 nm were observed on the YSZ surface, indicating the formation of an electrode/electrolyte interface induced under the cathodic polarization. ${ }^{19}$

\subsection{In situ assembled LSCF}

Fig. 2A shows polarization curves of a cell with an in situ assembled LSCF cathode at $500 \mathrm{~mA} \mathrm{~cm}{ }^{-2}$ and $750{ }^{\circ} \mathrm{C}$. The cell open circuit voltage was $1.10 \mathrm{~V}$ at $750{ }^{\circ} \mathrm{C}$, significantly higher than $\sim 0.80 \mathrm{~V}$ observed for doped ceria electrolyte based cells, ${ }^{21,22}$ indicating the inherently high electrochemical efficiency of YSZ electrolyte based cells. The initial peak power density (PPD) was $1.22 \mathrm{~W} \mathrm{~cm}^{-2}$ and it increased to $1.72 \mathrm{~W} \mathrm{~cm}^{-2}$ after polarization for $6 \mathrm{~h}$. This corresponds to a decrease of the $R_{\Omega}$ from $0.21 \Omega \mathrm{cm}^{2}$ to $0.14 \Omega \mathrm{cm}^{2}$ after polarization for $6 \mathrm{~h}$ (Fig. 2B). As the resistance of the YSZ electrolyte is not expected to change, the significant decrease in $R_{\Omega}$ indicates the formation of an effective LSCF electrode/YSZ electrolyte interface under the cathodic polarization. The electrode polarization resistance, $R_{\mathrm{E}}$, also decreased. The high initial cell performance indicates the promising potential of the in situ assembly approach in the direct utilization of CBP electrodes on YSZ electrolytes. However, the cell with the in situ assembled LSCF cathode is not stable and after polarization for $100 \mathrm{~h}$, the PPD reduced to $0.8 \mathrm{~W} \mathrm{~cm}^{-2}$ (Fig. 2C). The degradation of the cell performance is attributed to the increase of $R_{\mathrm{E}}$, as $R_{\Omega}$ remains more or less the same (Fig. 2B). Similar polarization behavior was also observed for the cell with an in situ assembled LSCF-GDC composite cathode (Fig. S3, ESI $\dagger$ ).

After the polarization test, the LSCF electrode was removed by using an adhesive tape and a distinct thin reaction layer was observed on the surface of the YSZ electrolyte (Fig. 2D). The layer thickness was in the range of 10-20 nm and ToF-SIMS analysis clearly shows that this reaction layer is rich in $\mathrm{Sr}$ (Fig. 2E and F). EDS-STEM analysis of the FIB-SEM prepared lamellae further confirms the formation of a Sr-rich layer along the electrode/electrolyte interface. This layer does not overlap with the YSZ electrolyte (Fig. $2 \mathrm{G}$ and S4, ESI $\dagger$ ), indicating that the reaction layer is probably in the form of SrO.

The formation of the SrO layer is most likely caused by the surface segregated Sr species from the LSCF electrodes. Sr surface segregation has been extensively reported for Sr-containing CBPs. ${ }^{23-25}$ As the chemical reaction between LSCF and YSZ starts at a higher temperature of $800{ }^{\circ} \mathrm{C}$ (Fig. 1B), the observation of the Sr-rich layer at the LSCF/YSZ interface at $750{ }^{\circ} \mathrm{C}$ indicates the significantly accelerated $\mathrm{Sr}$ segregation under the influence of
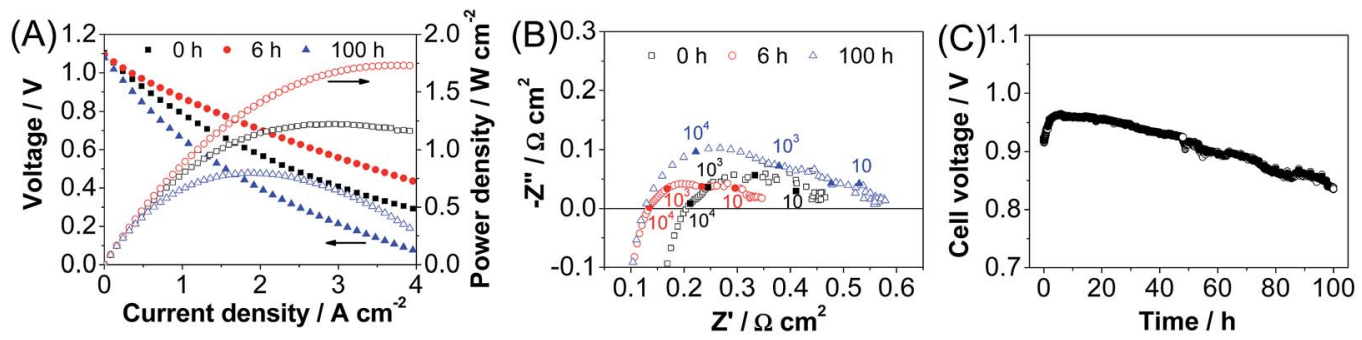

(D)

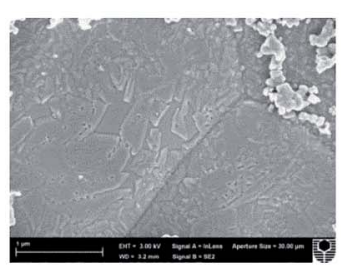

(G)

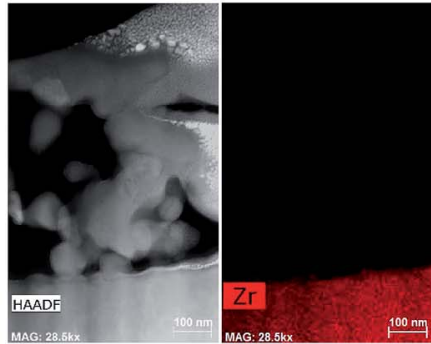

(E)

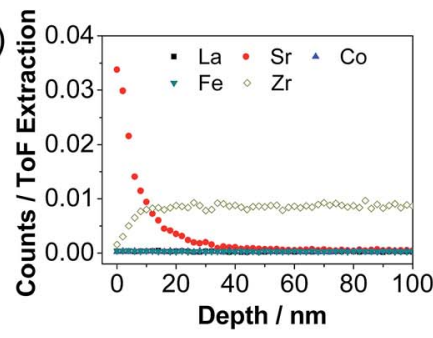

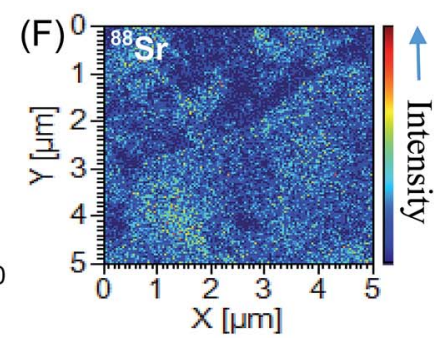
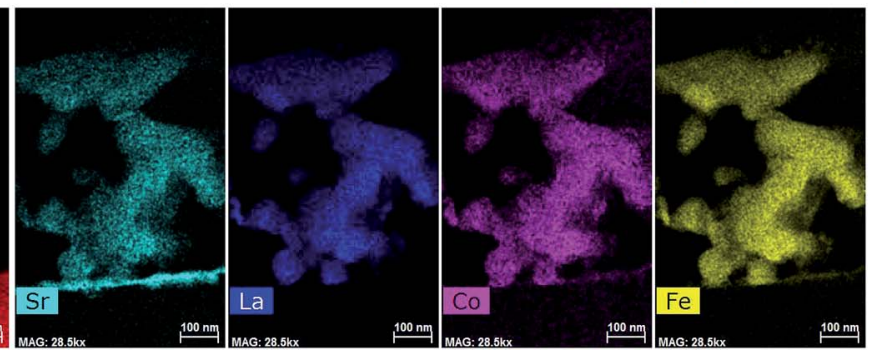

Fig. 2 Polarization performance of a cell with an in situ assembled pristine LSCF cathode as a function of polarization time at $750{ }^{\circ} \mathrm{C}$ and $500 \mathrm{~mA}$ $\mathrm{cm}^{-2}$ : (A) polarization curves, (B) impedance curves and numbers are frequencies in $\mathrm{Hz}$, and (C) stability curve. (D) SEM image of the YSZ electrolyte in contact with the LSCF electrode after polarization for $100 \mathrm{~h}$. LSCF was removed by using adhesive tape; (E) ToF-SIMS depth profiles and (F) Sr SIMS map of the YSZ surface (approx. top $10 \mathrm{~nm}$ ); and (G) STEM image and elemental maps at the LSCF cathode/YSZ electrolyte interface. 
cathodic polarization. This is consistent with the in situ SIMS analysis of the surface segregation and depletion of Sr species on LSM and $\mathrm{La}_{0.75} \mathrm{Sr}_{0.25} \mathrm{Cr}_{0.5} \mathrm{Mn}_{0.5} \mathrm{O}_{3}$ films under the influence of $\mathrm{dc}$ bias on the YSZ electrolyte. ${ }^{26,27}$ The gradual depletion of Sr from the LSCF lattice would significantly reduce the electrocatalytic activity, resulting in the performance degradation of the in situ assembled LSCF cathode as shown in this study.

\subsection{Suppression and elimination of $\mathrm{Sr}$ segregation}

The Sr segregation can be reduced by niobium doping at the B-site of the LSCF perovskite. ${ }^{28}$ XRD patterns of $\left(\mathrm{La}_{0.6} \mathrm{Sr}_{0.4}\right)_{0.95^{-}}$ $\mathrm{Co}_{0.2} \mathrm{Fe}_{0.7} \mathrm{Nb}_{0.1} \mathrm{O}_{3-\delta}$ (LSCFN)-YSZ couple powder show that the reaction temperature between LSCFN and YSZ is $850{ }^{\circ} \mathrm{C}$
(Fig. S5, ESI $\dagger$ ), which is $50{ }^{\circ} \mathrm{C}$ higher than that between LSCF and YSZ (see Fig. 1A). This shows the Nb doping enhances the chemical compatibility between LSCF and YSZ. Fig. 3A shows polarization curves of a cell with an in situ assembled $\left(\mathrm{La}_{0.6} \mathrm{Sr}_{0.4}\right)_{0.95}\left(\mathrm{Co}_{0.2} \mathrm{Fe}_{0.7} \mathrm{Nb}_{0.1}\right)_{0.95} \mathrm{Pd}_{0.05} \mathrm{O}_{3-\delta}$ (LSCFNPd) cathode. The purpose of the addition of $5 \% \mathrm{Pd}$ in the $\mathrm{B}$ site of LSCFN is to promote the diffusion and exchange processes of oxygen for the $\mathrm{O}_{2}$ reduction reaction..$^{29-31}$ The initial PPD is $0.54 \mathrm{~W} \mathrm{~cm}^{-2}$ and it increases gradually with the polarization, reaching $1.29 \mathrm{~W} \mathrm{~cm}^{-2}$ after polarization for $125 \mathrm{~h}$, which is much higher than $0.99 \mathrm{~W} \mathrm{~cm}^{-2}$ for a cell with an in situ assembled LSCFN without Pd doping (Fig. S6, ESI $\dagger$ ). This indicates that doping of a small amount of Pd is very effective in enhancing the electrocatalytic
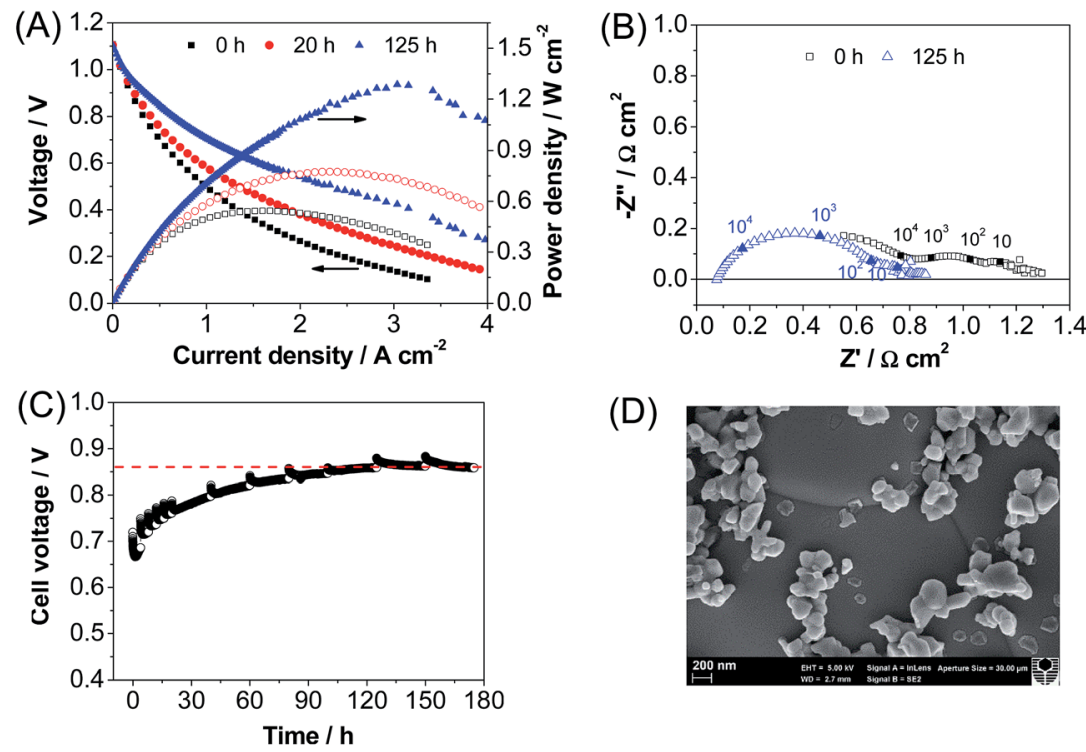

(D)
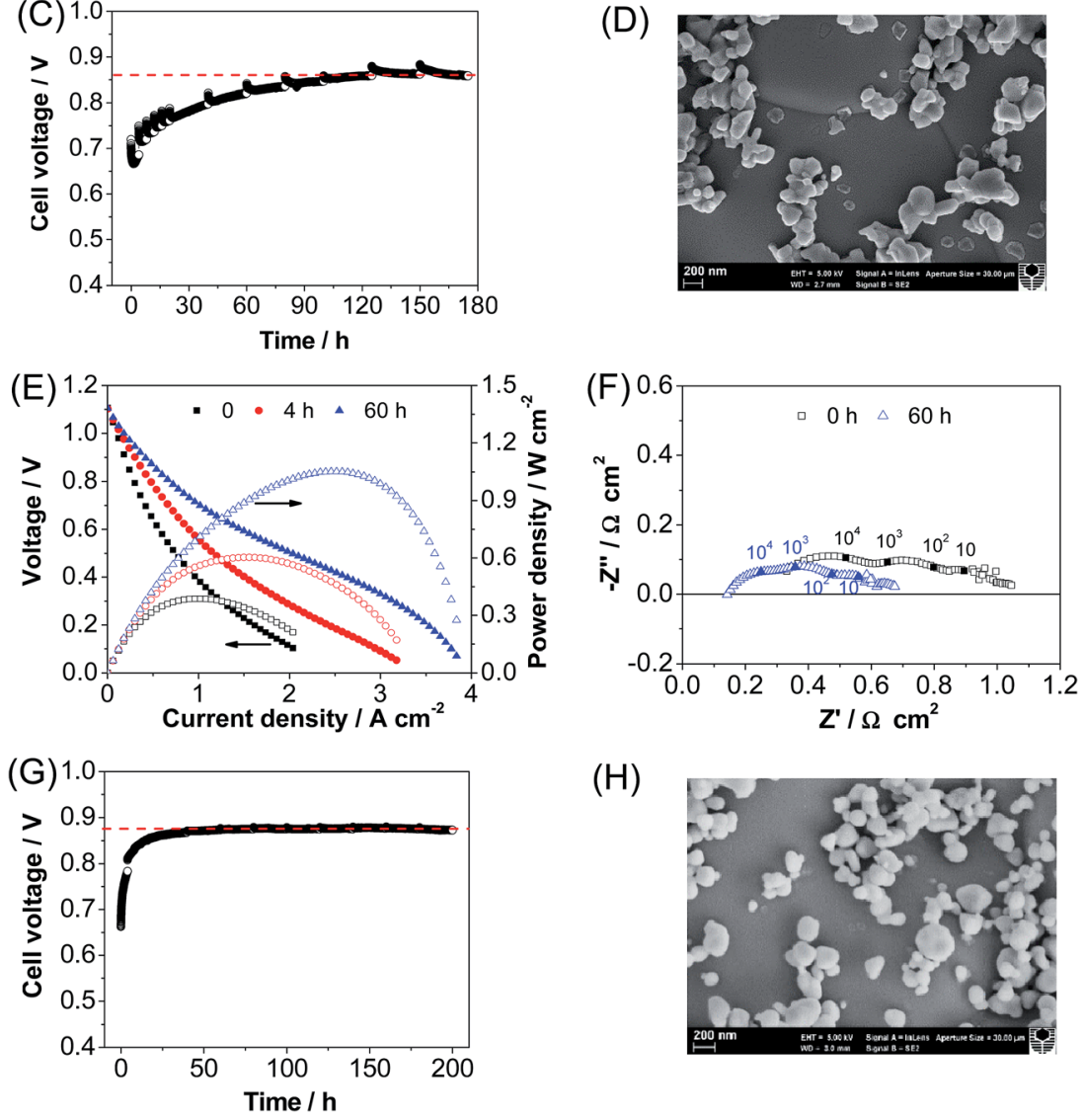

(H)

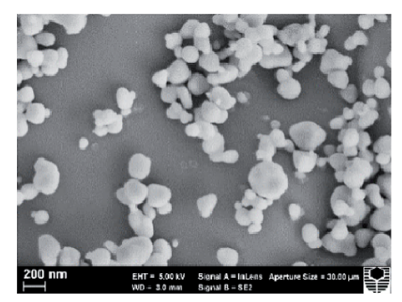

Fig. 3 Polarization performance of a cell with an in situ assembled pristine LSCFNPd cathode as a function of polarization time at $750{ }^{\circ} \mathrm{C}$ and 500 $\mathrm{mA} \mathrm{cm}{ }^{-2}$ : (A) polarization curves, (B) impedance curves and numbers are frequencies in $\mathrm{Hz}$, (C) stability curve, and (D) SEM image of the YSZ surface in contact with the cathode after the polarization. Polarization performance of a cell with an in situ assembled LCFPd-GDC composite cathode as a function of polarization time at $750{ }^{\circ} \mathrm{C}$ and $500 \mathrm{~mA} \mathrm{~cm}^{-2}$ : (E) polarization curves, (F) impedance curves and numbers are frequency in $\mathrm{Hz},(\mathrm{G})$ stability curve, and $(\mathrm{H})$ SEM image of the YSZ surface in contact with the cathode after the polarization. 
activity of the LSCFN electrode. The activation period of up to $125 \mathrm{~h}$ is much longer than the activation period of $6 \mathrm{~h}$ for LSCF. Nevertheless, the performance promotion is still due to the significant decrease in both $R_{\Omega}$ and $R_{\mathrm{E}}$ (Fig. 3B). There is also a change in the shapes of the impedance curves. Two arcs centered at $\sim 10 \mathrm{k}$ and $1 \mathrm{k} \mathrm{Hz}$ were observed before the polarization, and after the polarization for $125 \mathrm{~h}$, the arcs overlapped into a single arc centered at $1 \mathrm{k} \mathrm{Hz}$. This indicates that the polarization induced electrode/electrolyte interface formation also changes the electrode processes for the oxygen reduction reaction on the LSCFNPd cathode associated with the high frequency impedance of the cell..$^{32-34}$ The cell is stable at $500 \mathrm{~mA} \mathrm{~cm}{ }^{-2}$ and $750{ }^{\circ} \mathrm{C}$ (Fig. 3C). The YSZ electrolyte surface after the removal of the LSCFNPd by using adhesive tape shows the presence of LSCFNPd particles, but there is no formation of the distinct reaction layer as in the case of the LSCF cathode (Fig. 3D). This indicates that $\mathrm{Nb}$ doping is effective in suppressing the $\mathrm{Sr}$ surface segregation under SOFC operating conditions.

The stable performance of CBP cathodes can also be achieved by eliminating Sr. To confirm the concept, a Sr-free
$\mathrm{La}_{0.95}\left(\mathrm{Co}_{0.2} \mathrm{Fe}_{0.8}\right)_{0.95} \mathrm{Pd}_{0.05} \mathrm{O}_{3-\delta}$ (LCFPd) electrode was prepared. The cell with an in situ assembled LCFPd-GDC composite cathode showed an initial PPD of $0.39 \mathrm{~W} \mathrm{~cm}^{-2}$, and it increased to $1.05 \mathrm{~W} \mathrm{~cm}^{-2}$ after polarization for $60 \mathrm{~h}$ (Fig. 3E). The increase of PPD after polarization was similar to that observed for the cells with LSCF and LSCFNPd. The impedance study also showed a decrease of both $R_{\Omega}$ and $R_{\mathrm{E}}$ after polarization for $60 \mathrm{~h}$ (Fig. $3 \mathrm{~F}$ ). The cell performance was very stable during polarization up to $200 \mathrm{~h}$ (Fig. 3G), consistent with the absence of a thin reaction layer at the LCFPd-GDC/YSZ interface (Fig. $3 \mathrm{H}$ ).

Besides the La-containing CBP, other Sr-free CBPs like $\mathrm{Sm}_{0.95} \mathrm{Co}_{0.95} \mathrm{Pd}_{0.05} \mathrm{O}_{3-\delta}(\mathrm{SmCPd})$ can also be used. Fig. 4 shows the polarization performance of a cell with an in situ assembled SmCPd-GDC composite cathode. The initial PPD is $0.58 \mathrm{~W}$ $\mathrm{cm}^{-2}$ and it increases significantly to $1.40 \mathrm{~W} \mathrm{~cm}^{-2}$ after the polarization at $500 \mathrm{~mA} \mathrm{~cm}^{-2}$ for $150 \mathrm{~h}$ (Fig. 4A). Similar to the in situ assembled LCFPd-GDC cathode, the improvement of cell performance is attributed to the decrease of $R_{\Omega}$ and $R_{\mathrm{E}}$ under polarization (Fig. 4B). The cell with the in situ assembled SmCPd-GDC electrode is very stable at $500 \mathrm{~mA} \mathrm{~cm}^{-2}$ for $240 \mathrm{~h}$ (Fig. 4C), significantly better than the cells with the LSCF
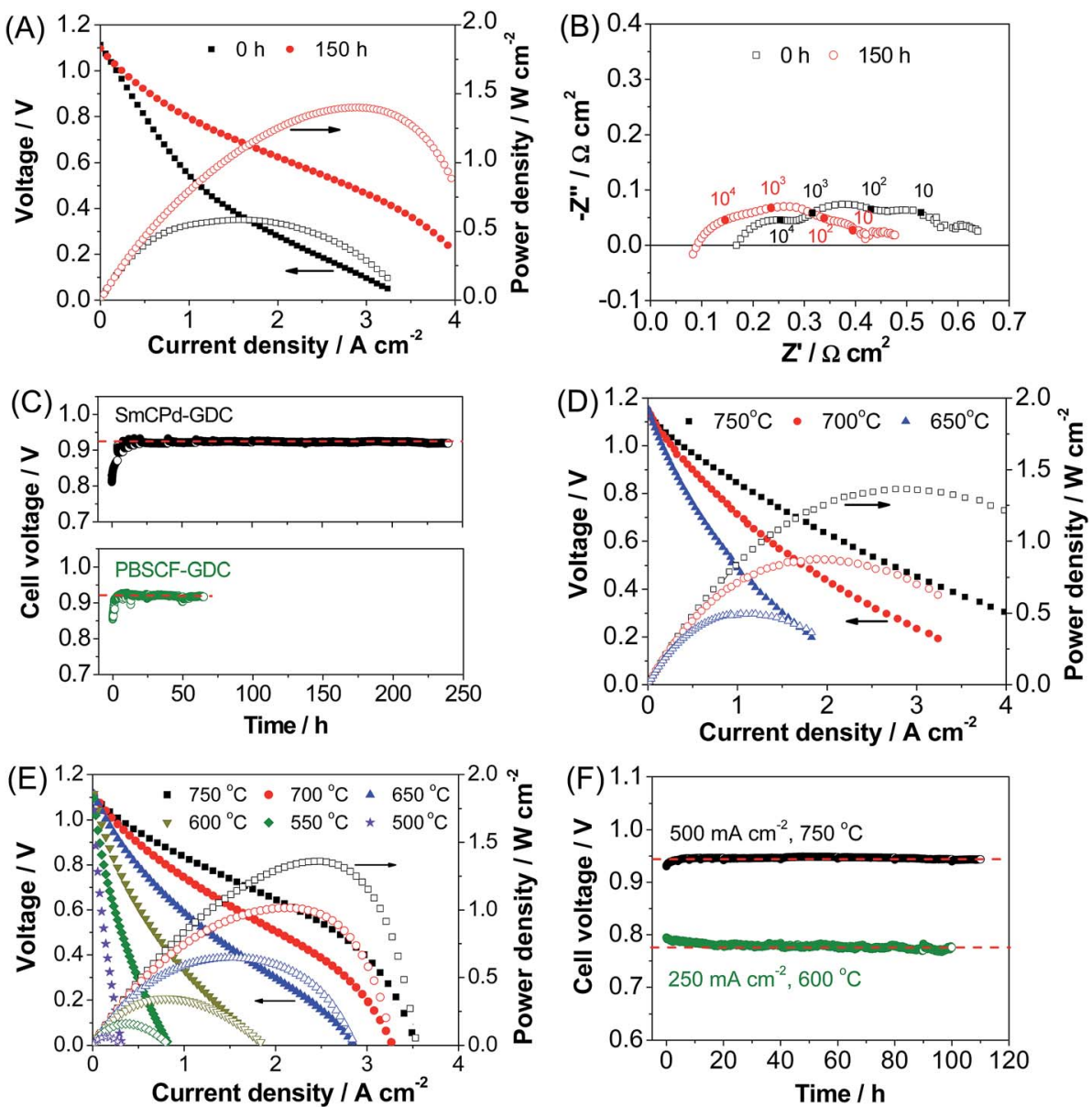

Fig. 4 Polarization performance of a cell with an in situ assembled SmCPd-GDC composite cathode as a function of polarization time at $750{ }^{\circ} \mathrm{C}$ and $500 \mathrm{~mA} \mathrm{~cm}^{-2}$ : (A) polarization curves, (B) impedance curves and numbers are frequencies in $\mathrm{Hz}$. (C) Stability curve of the cells with in situ assembled SmCPd-GDC and PBSCF-GDC composite cathodes at $750{ }^{\circ} \mathrm{C}$ and $500 \mathrm{~mA} \mathrm{~cm}^{-2}$. (D) Polarization curves of a cell with an in situ assembled PBSCF-GDC composite cathode at different temperatures. (E) Polarization curves of a cell with an in situ assembled LSMPt-YSB composite cathode at different temperatures, and (F) stability curves of the cell at $750{ }^{\circ} \mathrm{C}$ and $600{ }^{\circ} \mathrm{C}$. 
cathode under identical test conditions. This implies that Sr-free CBPs are very stable under the SOFC operating conditions at $750{ }^{\circ} \mathrm{C}$. In both LCFPd-GDC and SmCPd-GDC composite cathodes, the activation periods to reach a stable cell performance are significantly longer than that of Sr-containing CBP cathodes such as LSCF, but the underlying mechanism is not clear at the present stage.

\subsection{Utilization of a double perovskite and bismuth oxide}

A double perovskite oxide $\mathrm{PrBa}_{0.5} \mathrm{Sr}_{0.5} \mathrm{Co}_{1.5} \mathrm{Fe}_{0.5} \mathrm{O}_{5+\delta}$ (PBSCF) was also investigated as the in situ assembled cathode. Fig. 4C and $\mathrm{D}$ show the polarization performance and initial stability of a cell with an in situ assembled PBSCF-GDC composite cathode. After polarization at $500 \mathrm{~mA} \mathrm{~cm}{ }^{-2}$ and $750{ }^{\circ} \mathrm{C}$ for $2 \mathrm{~h}$, the PPDs reached $1.37,0.88$ and $0.50 \mathrm{~W} \mathrm{~cm}^{-2}$ at 750,700 and $650{ }^{\circ} \mathrm{C}$, respectively (Fig. 4D). The cell showed a reasonable stability (Fig. 4C).

The in situ assembly method also opens doors for the direct use of highly ionic conducting yet chemically active materials, e.g., doped bismuths such as $\mathrm{Y}_{0.5} \mathrm{Bi}_{1.5} \mathrm{O}_{3}$ (YSB), ${ }^{2,35}$ for YSZ electrolyte based SOFCs. A $\left(\mathrm{La}_{0.8} \mathrm{Sr}_{0.2}\right)_{0.95} \mathrm{Mn}_{0.95} \mathrm{Pt}_{0.05} \mathrm{O}_{3-\delta}$ (LSMPt) perovskite was prepared and mixed with YSB to form a LSMPt-YSB composite cathode. The cell with the in situ assembled LSMPt-YSB cathode showed very good performance at intermediate temperatures, achieving a PPD of 1.36, 1.02, $0.65,0.35,0.16$ and $0.06 \mathrm{~W} \mathrm{~cm}^{-2}$ at 750, 700, 650, 600, 550 and $500{ }^{\circ} \mathrm{C}$, respectively (Fig. $4 \mathrm{E}$ ). The cell exhibited a very stable performance, achieving a cell voltage of $0.94 \mathrm{~V}$ at $500 \mathrm{~mA} \mathrm{~cm} \mathrm{~cm}^{-2}$ and $750{ }^{\circ} \mathrm{C}$ and $0.78 \mathrm{~V}$ at $250 \mathrm{~mA} \mathrm{~cm}{ }^{-2}$ and $600{ }^{\circ} \mathrm{C}$ for over $100 \mathrm{~h}$ (Fig. 4F). The PPD of $0.06 \mathrm{~W} \mathrm{~cm}{ }^{-2}$ at $500{ }^{\circ} \mathrm{C}$ is also very encouraging because both the LSMPt-YSB cathode and the Ni-YSZ anode supported cell structure are far from optimization in the current study. This demonstrates that with the in situ assembly approach it is feasible to attain a high performance and operationally stable cell at low operating temperatures, even with the LSM cathode material originally developed for high temperature SOFCs.

\section{Conclusions}

Our findings represent an innovative approach with greatly simplified fabrication steps and substantially advance the direct application of highly active CBP cathodes on the YSZ electrolyte for IT-SOFCs. The performance degradation of Sr-containing CBPs due to the Sr segregation can be effectively reduced or eliminated by $\mathrm{Nb}$ doping at the B-site, by using Sr-free or alternative CBPs such as double perovskites as shown in this study. The elimination of processing sintering steps and the simplicity of the in situ assembly process enable the incorporation of highly active but chemically and thermally unstable materials such as CBPs and doped bismuth to substantially enhance the electrocatalytic activity and stability of SOFCs. Addition of a small amount of active metals such as Pd or Pt is also very effective in increasing the performance of in situ assembled cathodes. The in situ assembly approach could also provide a feasible pathway to directly use CBP oxygen electrodes in YSZ electrolyte based solid oxide electrolysis cells.

The most important outcome of the current study is that for the first time we show that high temperature sintering is not an absolute requirement for the formation of a solid/solid interface as generally believed in the field. An excellent electrode/electrolyte interface can be formed in situ under fuel cell operating conditions at temperatures as low as $750{ }^{\circ} \mathrm{C}$. The in situ formed interface has significant advantages over the traditional high temperature sintering processes, which not only opens new avenues for the direct use of vast range of MIEC CBP materials in YSZ based SOFCs, but also has a significant scientific impact on the fundamental understanding of the formation of solid/solid interfaces in general.

\section{Acknowledgements}

The project is supported by the Curtin University Research Fellow Program, the National Natural Science Foundation of China (U1134001), the Australian Research Council under the Discovery Project scheme (project numbers: DP150102025 \& DP150102044) and the Science and Industry Endowment Fund. The authors acknowledge the facilities, scientific and technical assistance of the Curtin University Microscopy \& Microanalysis Facility and UWA Centre for Microscopy, Characterisation and Analysis, both of which are funded by the University, State and Commonwealth Governments, and the Department of Chemistry/Nanochemistry Research Institute, Curtin University.

\section{Notes and references}

1 N. Q. Minh, J. Am. Ceram. Soc., 1993, 76, 563-588.

2 E. D. Wachsman and K. T. Lee, Science, 2011, 334, 935-939.

3 L. C. De Jonghe, C. P. Jacobson and S. J. Visco, Annu. Rev. Mater. Res., 2003, 33, 169-182.

4 S. P. Jiang, J. Mater. Sci., 2008, 43, 6799-6833.

5 S. Yoo, A. Jun, Y.-W. Ju, D. Odkhuu, J. Hyodo, H. Y. Jeong, N. Park, J. Shin, T. Ishihara and G. Kim, Angew. Chem., Int. Ed., 2014, 53, 13064-13067.

6 Z. P. Shao and S. M. Haile, Nature, 2004, 431, 170-173.

7 S. P. Jiang, Solid State Ionics, 2002, 146, 1-22.

8 A. Esquirol, J. Kilner and N. Brandon, Solid State Ionics, 2004, 175, 63-67.

9 J. Fleig, Annu. Rev. Mater. Res., 2003, 33, 361-382.

10 O. Yamamoto, Y. Takeda, R. Kanno and M. Noda, Solid State Ionics, 1987, 22, 241-246.

11 H. Yokokawa, Annu. Rev. Mater. Res., 2003, 33, 581-610.

12 R. Kiebach, W.-W. Zhang, W. Zhang, M. Chen, K. Norrman, H.-J. Wang, J. R. Bowen, R. Barfod and P. V. Hendriksen, J. Power Sources, 2015, 283, 151-161.

13 S. Sengodan, S. Choi, A. Jun, T. H. Shin, Y. W. Ju, H. Y. Jeong, J. Shin, J. T. S. Irvine and G. Kim, Nat. Mater., 2015, 14, 205209.

14 X. D. Zhou, B. Scarfino and H. U. Anderson, Solid State Ionics, 2004, 175, 19-22.

15 A. Mai, V. A. C. Haanappel, F. Tietz and D. Stover, Solid State Ionics, 2006, 177, 2103-2107. 
16 Z. G. Lu, X. D. Zhou, J. Templeton and J. W. Stevenson, J. Electrochem. Soc., 2010, 157, B964-B969.

17 N. Jordan, W. Assenmacher, S. Uhlenbruck, V. A. C. Haanappel, H. P. Buchkremer, D. Stöver and W. Mader, Solid State Ionics, 2008, 179, 919-923.

18 S. P. Simner, M. D. Anderson, M. H. Engelhard and J. W. Stevenson, Electrochem. Solid-State Lett., 2006, 9, A478-A481.

19 S. P. Jiang, J. Electrochem. Soc., 2015, 162, F1119-F1128.

20 K. F. Chen, Z. Lu, N. Ai, X. Q. Huang, Y. H. Zhang, X. D. Ge, X. S. Xin, X. J. Chen and W. H. Su, Solid State Ionics, 2007, 177, 3455-3460.

21 Q. J. Zhou, Y. C. Zhang, Y. Shen and T. M. He, J. Electrochem. Soc., 2010, 157, B628-B632.

22 C. R. Xia and M. L. Liu, Solid State Ionics, 2001, 144, 249-255.

23 M. Kubicek, A. Limbeck, T. Frömling, H. Hutter and J. Fleig, J. Electrochem. Soc., 2011, 158, B727-B734.

24 D. Oh, D. Gostovic and E. D. Wachsman, J. Mater. Res., 2012, 27, 1992-1999.

25 H. Ding, A. V. Virkar, M. Liu and F. Liu, Phys. Chem. Chem. Phys., 2013, 15, 489-496.
26 A.-K. Huber, M. Falk, M. Rohnke, B. Luerben, L. Gregoratti, M. Amati and J. Janek, Phys. Chem. Chem. Phys., 2012, 14, 751-758.

27 A.-K. Huber, M. Falk, M. Rohnke, B. Luerssen, M. Amati, L. Gregoratti, D. Hesse and J. Janek, J. Catal., 2012, 294, 79-88.

28 X. B. Chen and S. P. Jiang, J. Mater. Chem. A, 2013, 1, 48714878.

29 F. L. Liang, J. Chen, J. L. Cheng, S. P. Jiang, T. M. He, J. Pu and J. Li, Electrochem. Commun., 2008, 10, 42-46.

30 T. H. Shin, Y. Okamoto, S. Ida and T. Ishihara, Chem.-Eur. J., 2012, 18, 11695-11702.

31 D. M. Bierschenk, E. Potter-Nelson, C. Hoel, Y. G. Liao, L. Marks, K. R. Poeppelmeier and S. A. Barnett, J. Power Sources, 2011, 196, 3089-3094.

32 S. McIntosh, J. M. Vohs and R. J. Gorte, J. Electrochem. Soc., 2003, 150, A1305-A1312.

33 N. Ai, K. Chen, S. P. Jiang, Z. Lü and W. Su, Int. J. Hydrogen Energy, 2011, 36, 7661-7669.

34 K. Chen, L. Zhang, N. Ai, S. Zhang, Y. Song, Y. Song, Q. Yi, C.-Z. Li and S. P. Jiang, Energy Fuels, 2016, 30, 1849-1857.

35 N. M. Sammes, G. A. Tompsett, H. Näfe and F. Aldinger, J. Eur. Ceram. Soc., 1999, 19, 1801-1826. 